\title{
Flexible resins: an esthetic option for partially edentulous patients
}

\author{
Resinas flexíveis: uma opção estética para desdentados parciais
}

Simone Guimarães Farias GOMES 1

Altair Antoninha Del Bel CURY'

\begin{abstract}
Flexible thermoplastic resins have been used as an alternative to partially edentulous patients for decades in the USA. However, they are neither popular nor widespread in Brazil. This material represents an excellent treatment option to solve clinical problems such as compromised esthetics caused by visible metal clasps, and fall fracture of dentures made of conventional resins. Additionally, there is little researching and no controlled clinical studies about the use of flexible resins in prosthodontics. For these reasons, this study presents a case report of a dissatisfied patient treated with a conventional removable partial denture, which was replaced by a modified metal framework without metal clasps in combination with flexible resin, and a literature review about this material focusing on the dental practitioner. The study also reports how these polymers can be used, their indications, and their clinical and laboratory considerations.
\end{abstract}

Indexing terms: Acetates. Denture, removable partial. Nylons.

\section{RESUMO}

As resinas termoplásticas flexíveis têm sido uma alternativa para tratamento de pacientes parcialmente desdentados disponível há décadas nos EUA. No Brasil, no entanto, ainda são pouco utilizadas e conhecidas. Este material pode representar uma excelente opção de tratamento reabilitador, para solucionar problemas tais como o aparecimento de grampos metálicos com comprometimento da estética e fratura de próteses confeccionadas com resinas convencionais devido a quedas. Além disso, pesquisas acerca desse material são escassas e não há estudos clínicos de sua utilização na área de prótese dentária na literatura. Por essas razões, este estudo apresenta um caso clínico de uma paciente insatisfeita tratada com prótese removível convencional, a qual foi substituída por uma estrutura metálica modificada sem grampos em combinação com resina, e uma revisão da literatura, com o objetivo de elaborar um apanhado de informações para o clínico sobre estes materiais, além de apresentar como estes polímeros podem ser utilizados, as suas indicações em prótese parcial removível, suas considerações clínicas e laboratoriais.

Termos de indexação: Acetatos. Prótese parcial removível. Nylons.

\section{INTRODUCTION}

Prosthetic rehabilitation should be able to recover patients' function and esthetics. However, conventional removable partial dentures (RPDs) are fabricated on a metal framework that uses clasps for retention. The clasps are usually visible when the patient smiles. These visible components occasionally cause dissatisfaction, leading patients to reject treatment ${ }^{1}$ because of how they attribute maximum importance of their smile to their self-esteem and to their personal, social, and professional relationships².

Some resources are available for promoting better esthetics, such as attachment-retained removable partial dentures. However, this type of treatment has higher biological and financial costs since abutment teeth need to be prepared to receive fixed partial dentures ${ }^{1}$. Another esthetic solution is the rotational path removable partial denture, which can have excellent results but its indication is very limited and fabrication technique very sensitive ${ }^{3}$. Careful planning of removable partial dentures, such as the use of the distal surfaces for retention and bar clasps instead of circumferential clasps ${ }^{4}$, can yield better esthetic results. A favorable esthetic result can also be reached by changing the design of the metal structure by using a lingual retentive arm and leaving the labial side metal free ${ }^{5}$. This requires the fabrication of a plane guide on the free proximal surface of the abutment tooth such that this plane, parallel to the insertion axis of the denture, receives a proximal plate, which has a reciprocity function ${ }^{1,5}$ originally performed by the reciprocal arm. Despite all these resources, sometimes it is not possible to provide good esthetics, usually leaving the metal used for the framework visible ${ }^{4}$.

\footnotetext{
${ }^{1}$ Universidade Estadual de Campinas, Faculdade de Odontologia, Departamento de Prótese e Periodontia. Av. Limeira, 901, Areião, 13414-903, Piracicaba, SP, Brasil. Correspondência para / Correspondence to: SGF GOMES. E-mail: <monegfg@hotmail.com>.
} 
Although conventional acrylic resins (polymethyl methacrylate-PMMA) offer appropriate esthetics, they do not meet all the mechanical requirements imposed on removable partial dentures ${ }^{6}$ since PMMA is subject to mechanical failures and dimensional changes, and may cause allergic reactions ${ }^{7}$. Many polymers have already been introduced or developed over time to improve PMMA's physical properties ${ }^{8}$. Some such polymers include the flexible resins introduced in the 1950s for denture purposes, considered a material of great potential in dentistry 9 . These resins may be used for replacing PMMA and/or the metal framework, the materials used in the fabrication of conventional RPDs ${ }^{10}$.

The flexible materials used for the fabrication of RPDs are thermoplastic resins. They differ from conventional resins by not undergoing chemical reactions during the laboratory process. Thermoplastic resins undergo only physical changes when heated, as they become soft and can be injected under pressure into a preheated refractory mold, where it solidifies as it cools $s^{9,11}$. Flexible thermoplastic resins used for fabricating RPDs include polyamides or nylons, and acetate or polyoxymethylene resins.

\section{Polyamide or nylon}

Polyamide was introduced in the market for the fabrication of flexible RPD decades ago, at a time when it did not have the required characteristics for the fabrication of appropriate dentures ${ }^{9}$. Today, polyamide derives from diamine and dibasic monomer acids. It has high chemical, thermal, and physical resistances ${ }^{10}$, is clinically unbreakable, absorbs little water, and is color stable ${ }^{9}$.

Polyamide can be used in many ways: it can replace the metal framework and conventional resin used in totally flexible and metal-free RPDs, bracing the abutment teeth and mimicking gingival tissues, ${ }^{9,2}$; it can be combined with the metal framework, replacing the $\mathrm{Co}-\mathrm{Cr}$ retentive arms with flexible clasps that mimic the gum and the conventional resins in the base; and as prefabricated clasps in the color of the teeth connected to the metal framework or to conventional resins ${ }^{9}$. Some commercial brands include Flexite (The Flexite Company, Mineola, NY, EUA) and Valplast (Valplast Internationl Corp., Long Island City, NY, EUA).

\section{Acetate or polyoxymethylene resin}

Formed by formaldehyde polymerization, acetate resin is a very strong flexible material that resists wear and tear $^{10}$. These characteristics make it an ideal material for denture bases, prefabricated clasps, and RPD frameworks, replacing metal ${ }^{10,13}$ and promoting better esthetics. Although acetate resins are flexible, they are harder than polyamide, so an acetate framework can also be combined with PMMA bases ${ }^{11}$. On the other hand, because of the ordered carbon chain, acetate resins are opaque, not having the esthetically desirable translucency and vitality ${ }^{10,11}$.

According to Arikan et al. ${ }^{13}$, acetate resins absorb less water and are less soluble than PMMA, although both polymers meet international specifications (ISO). Acetate resins are similar to PMMA with respect to color stability ${ }^{14}$. Examples of commercial brands include TSM Acetal Dental (Pressing Dental Company, Dogana, San Marino) and Dental D (Biodent, Goodna, Australia).

\section{Advantages and disadvantages of using flexible resins in RDPs}

Many patients are dissatisfied with their RDPs because of the metal clasps, especially clasps in the anterior region ${ }^{1,15}$. Dentures made from flexible resins can be totally metal free or contain metal parts. Resin clasps are made in the same color of the teeth or in translucent pink resin, mimicking the gums ${ }^{10}$. These characteristics make such RPDs unarguably more esthetic ${ }^{16}$.

Metal-free flexible-resin RDPs are lighter and more comfortable ${ }^{16}$. Moreover, they are more resistant than the traditional nonflexible RPDs ${ }^{10,17}$. Polyamide RPDs are clinically unbreakable ${ }^{9}$.

The water absorptivity of resins is important because it changes RPD dimensions and worsens its mechanical properties. Acetate resins absorb less water than PMMA but have the same color stability ${ }^{13,14}$. Solubility regards the mass of soluble materials in the polymers, such as nonreactive and plastifying monomers, and primers ${ }^{18}$. Acetate resins are less soluble, thus better than conventional acrylic resins ${ }^{13}$. Contrary to PMMA, both acetate and polyamide resins have very little or no residual monomers ${ }^{10}$.

Generally, thermoplastic resins are not very porous, reducing the formation of biofilm and pigmentation, avoiding malodor, and increasing dimensional and color stability ${ }^{10}$. However, a recent study found that after 72 hours, polyamide resin had more microorganism growth than conventional acrylic resin. However, microorganisms were reduced or eliminated in both resins after treatment with chemical cleaners and $0.5 \%$ sodium hypochlorite, respectively ${ }^{19}$.

Polyamide does not adhere to acrylic resins in the same way that new increments of flexible resin cannot be added to a finished denture, even if the denture is made from the same material, usually preventing rebasing and 
repairs ${ }^{11}$. Nevertheless, some manufacturers state that dentures can be rebased and repaired properly using cyanoacrylate as a bonding agent ${ }^{9}$. Acetate resin can be rebased and repaired when used as framework and combined with acrylic resin bases ${ }^{11}$.

It is important to point out that there are no clinical studies about microorganism colonization and growth on polyamide dentures or about the effect of cleaners on the characteristics of this material.

The absence of longitudinal clinical studies with patients wearing flexible-resin dentures is an important disadvantage. Hence, how oral tissues respond to longterm exposure to these polymers is unknown. Additionally, many resin behavior-related parameters have not been established, such as microorganism growth on flexible resins and the effect of chemical dental cleaners and sodium hypochlorite on their characteristics.

\section{Flexible resin indications}

Flexible resins are indicated in cases where esthetic requirements cannot be met by other types of dentures because of biomechanical or physiological reasons or the patient's will ${ }^{1}$

Acetate and polyamide resins do not have residual polymers, therefore, flexible RPDs can be indicated for patients who may be allergic to these substances or patients allergic to $\mathrm{Co}-\mathrm{Cr}^{17,20,21}$.

They are also indicated for patients with a bulky torus palatinus, palatine cleft, propensity to break dentures, and morphological intolerance to hard acrylic bases, such as knife-edge ridge ${ }^{16}$.

According to Samet et al. ${ }^{12}$, flexible PRDs may also be indicated in any situation of microstomia and compromised manual dexterity stemming from a systemic condition, such as patients with systemic sclerosis or patients with severe burn or traumatic scars.

\section{Clinical considerations}

A great benefit of flexible metal-free RPDs is the small oral preparation required. Component flexibility reduces the interferences during denture insertion and removal. The fabrication of guide planes and eventual wear on the surfaces of the reciprocal arms are considered inconsequential ${ }^{11}$.

VandenBrink et al. ${ }^{22}$ assessed the behavior of RPD clasps made from noble metal alloys, basic alloys, and flexible resin. They observed that flexible-resin clasps change permanently after a deformation of approximately $0.76 \mathrm{~mm}$. Therefore, when flexible-resin denture models are designed, one should use a calibration retainer rest of $0.50 \mathrm{~mm}$, that is, the flexible-resin clasps should be placed in deeper retainer areas because of their greater flexibility ${ }^{4,23}$.

Furthermore, only the active edge of the retentive arm of a conventional denture should be below the denture's equator to promote retention. Nonetheless, polyamide dentures require some millimeters of contact between the material and the tooth and gum tissues to promote adequate retention and stability. Thus, sometimes enameloplasty with a diamond burr is required for perfect adaptation on the dental structure, achieving contact between the denture and oral structures ${ }^{24}$.

In addition to the material used for fabricating the clasps, other aspects should be considered, such as arm length, width, cross-section, and curvature radius. To obtain hardness similar to a Co-Cr clasp with a length of $15 \mathrm{~mm}$ and diameter of $1 \mathrm{~mm}$, an acetate resin clasp should be shorter, approximately $5 \mathrm{~mm}$ in length and 1.4 $\mathrm{mm}$ in diameter ${ }^{4}$. Polyamide dentures are extremely stable, retentive, and almost unbreakable, and usually made in shades of pink. Clasps made from this polymer surround the neck of the tooth and because they are not very thick, they are translucent, mimicking the gum ${ }^{10}$ and promoting the desired natural look.

An important fact reported by Quagliatto et al. ${ }^{15}$ is that metal-free acetate-resin RPDs should be fabricated very carefully following a number of criteria. Naturally, conventional dentures should also be fabricated in this manner, but in the case of metal-free acetate-resin RPDs, the laboratory receives the model made by the dentist mounted on a semi-adjustable articulator and returns a RPD ready for insertion.

It is important to always bear in mind that flexible resins are polymers that differ from conventional acrylic resins, so they should be treated differently. For example, it is often necessary to make adjustments when inserting a RPD for the first time and performing maintenance. These adjustments should be made by rubber burrs as recommended by the manufacturers, and not by tungsten carbide burrs, like those used for PMMA-based acrylic resins ${ }^{24}$.

\section{CASE REPORT}

This is the case report of a 53-year-old, partially edentulous female patient who was very dissatisfied with a recently installed upper removable partial denture. She was mainly dissatisfied with the metal clasp that was visible when she smiled (Figure 1). Hence, a polyamide RPD was indicated to satisfy the patient's needs. Since only 
the elements 13 and 23 were present in the upper arch, a metal structure was indicated to provide more support to the teeth and ridge, combined with polyamide base and clasps to ensure better esthetics (Figure 2). To obtain the desired flexibility, the material would have to be thin,

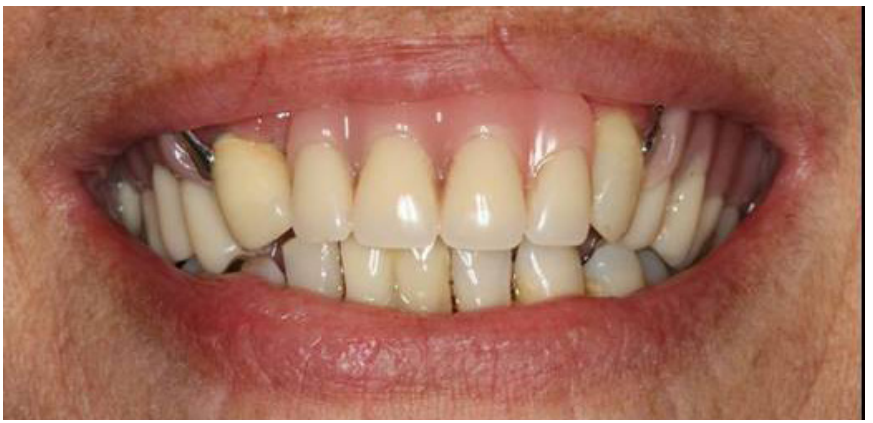

Figure 1. Conventional RPD with visible metal clasps on elements 13 and 23
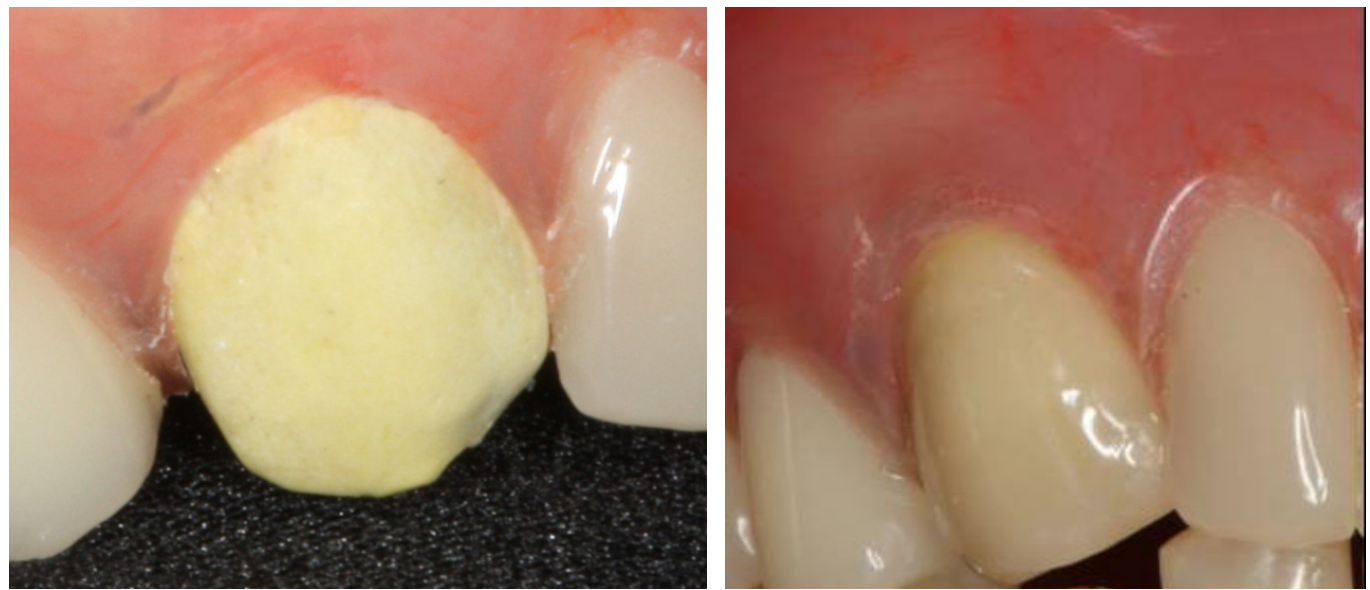

Figure 3. Side view of the denture. A) on the model; B) in the patient's mouth. Detail of the circumferential clasp on the region of element 13. Notice how the translucency of the material mimecs the gingival tissues.

\section{Laboratory considerations}

Inexperienced technicians take longer to fabricate polyamide RPDs than PMMA RPDs using injection. After proper training, both RPDs required similar times to fabricate, sometimes less time to fabricate polyamide RPDs $^{25}$. More dexterity is required to adjust and polish polyamide RPDs ${ }^{10}$. Better polishing is achieved with rubber burrs and polishing paste ${ }^{4}$.

\section{DISCUSSION}

Flexible RPDs are an excellent treatment option for partially edentulous patients not only because of their conferring translucency and a natural appearance (Figure 3). The patient was very satisfied with the final result.

The patient signed an informed consent form agreeing with the proposed treatment and the disclosure of her photographs.

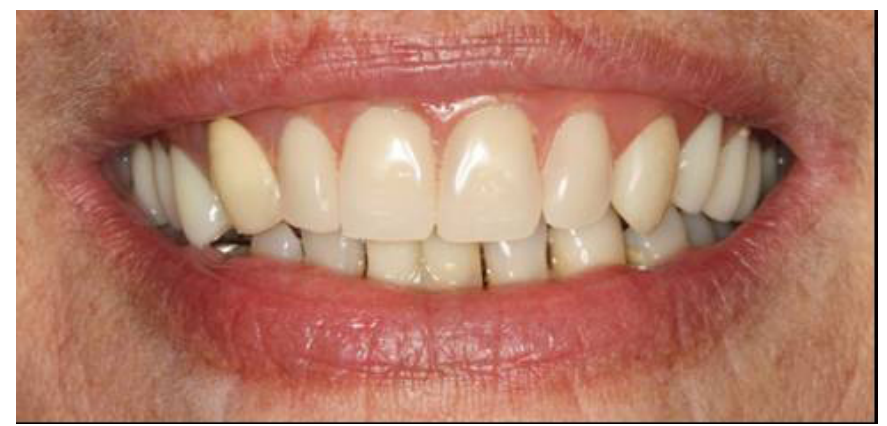

Figure 2. Polyamide RPD with a Co-Cr framework using clasps on elements 13 and 23 . 
Dimensional precision and stability $9,10,13,25,26$ as well as the physical behavior of acetate and polyamide resins regarding elasticity ${ }^{27}$, fracture resistance, and shock resistance ${ }^{17}$ favored their use in RPD fabrication.

Arda \& Arikan ${ }^{23}$ reported that $\mathrm{Co}-\mathrm{Cr}$ clasps had deformed significantly after six months of clinical use, and continued to lose retention strength until the 36th month of simulation. On the other hand, acetate clasps do not deform after the same period ${ }^{23}$; the elasticity of flexible clasps last indefinitely ${ }^{10}$, showing that their mechanical behavior is also very favorable. Yet, the retentive force of $\mathrm{Co}-\mathrm{Cr}$ clasps remained significantly higher than that of acetate clasps during the entire study period ${ }^{23}$.

A patient with oral and manual dexterity limitations due to systemic disease rehabilitated with a flexible RPD was very satisfied with the treatment, handling the denture well and presenting satisfactory function and excellent condition of the tissues adjacent to the RPD after three years of use ${ }^{12}$. Vacek ${ }^{25}$ also did not find adverse effects on

\section{REFERENCES}

1. Chu $\mathrm{CH}$, Chow, TW. Esthetic designs of removable partial dentures. Gen Dent. 2003;51(4):322-4.

2. Kreidler MM, Rodrigues CD, Souza RF, Oliveira Junior OB. Ficha de anamnese estética: sua aplicação para identificar opinião pessoal, critério de julgamento, importância atribuída e modelo de referência estética. RGO - Rev Gaúch Odontol. 2005;53(1):17-21.

3. Byron R Jr, Frazer RQ, Herren MC. Rotational path removable partial denture: an esthetic alternative. Gen Dent. 2007;55(3):245-50.

4. Turner JW, Radford DR, Sherriff M. Flexural properties and surface finishing of acetal resin denture clasps. J Prosthod. 1999:8(3):188-95

5. Brudvik JS, Palacios R. Lingual retention and the elimination of the visible clasp arm. J Esthet Restor Dent. 2007;19(5):247-54.

6. Darbar UR, Huggett $R$, Harrrison A. Denture fracture: a survey. $\mathrm{Br}$ Dent J. 1994;176(9):342-5.

7. Sadamori S, Kotani H, Hamada T. The usage period of dentures and their residual monomer contents. J Prosthet Dent. 1992;68(2):374-6.

8. Stafford GD, Bates JF, Hugett R, Handley RW. A review of the properties of some denture base polymers. J Dent. 1980;8(4):292-306.

9. De Luca A. The unique thermoplastic injected partial-Flexite. Trends Tech Contemp Dent Lab. 1987;4(2):30-3. the anatomic structures of any patient who used polyamide RPDs for six months. However, there are no studies with enough evidence to indicate flexible RPDs as unconditional replacements for conventional RPDs made from $\mathrm{Co}-\mathrm{Cr}$ and PMMA.

\section{CONCLUSION}

RPDs made from acetate and polyamide resins have a high potential for the rehabilitation of partially edentulous patients, and their favorable characteristics allow them to be used without concerns when well indicated.

\section{Collaborators}

SGF GOMES was responsible for treating the patient and writing the manuscript. AA DEL BEL CURY was responsible for the clinical and manuscript writing supervision and helped to write the article.
10. Negrutiu $M$, Sinescu C, Romanu M, Pop D, Lakatos S Thermoplastic resins for flexible framework removable partial dentures. Timisoara Medical Journal. 2005;55(3):295-9.

11. Ewoldsen N. What are the clinical disadvantages and limitations associated with metal-free partial dentures? J Can Dent Assoc. 2007;73(1):45-6.

12. Samet N, Tau S, Findler M, Susarla S, Findler M. Flexible, removable partial denture for a patient with systemic sclerosis (scleroderma) and microstomia. Gen Dent. 2007;55(6):548-51.

13. Arikan A, Ozkan YK, Arda T, Akalin B. An in vitro investigation of water sorption and solubility of two acetal denture base materials. Eur J Prosthodont Rest Dent. 2005;13(3):119-22.

14. Ozkan Y, Arikan A, Akalin B, Arda T. A study to assess the color stability of acetal resins subjected to thermocycling. Eur J Prosthodont Rest Dent. 2005;13(1):10-4.

15. Quagliatto OS, Costa MM, Oliveira JE. Removível com grampos estéticos: nova solução estética para próteses parciais removíveis (Próteses "Metal Free" - Tipo Dental D). RGO - Rev Gaúch Odontol. 2000;48(2):82-4.

16. Chi $H$, Mendez M, Hanson K. Use of a thermoplastic resin stayplate as an alternative to an acrylic stayplate: a case report. Gen Dent. 2007;55(2):125-8.

17. Stafford GD, Hugget R, MacGregor AR, Graham J. The use of nylon as a denture-base material. J Dent. 1986;14(1):18-22.

18. Cucci ALM, Vergani CE, Giampaolo ET, Afonso MCS. Water absorption, solubility, and bond strengh of two auto polymerizing acrylic resins and one heat-polymerizing acrylic resin. J Prosthet Dent. 1998:80(4):434-8. 
19. Fernandes FSF. Efeito de limpadores químicos sobre biofilmes de Candida formados sobre a superfície de materiais para base de próteses removíveis [dissertação]. Campinas: Universidade Estadual de Campinas; 2010.

20. McGregor AR, Graham J, Stafford GD, Huggett R. Recent experiences with denture polymers. J Dent. 1984;12(2):146-57.

21. Pfeiffer $P$, Rolleke $C$, Sherif L. Flexural strength and moduli of hypoallergenic denture base materials. J Prosthet Dent. 2005;93(4):372-7.

22. VandenBrink JP, Wolfaardt JF, Faulkner MG. A comparison of various removable partial denture clasp materials and fabrication procedure for placing clasps on canine and premolar teeth. J Prosthet Dent. 1993;70(2):180-8.

23. Arda $\mathrm{T}$, Arikan $\mathrm{A}$. $\mathrm{Na}$ in vitro comparison of retentive force and deformation of acetal resin and cobalt-cromium clasps. J Prosthet Dent. 2005;94(3):267-74.

24. Kaplan P. Flexible removable partial dentures: design and clasp concepts. Fairfield, 2008. [cited 2010 Apr 7]. Available from: <http://www.dentistrytoday.com/ME2/dirmod.asp?sid=\&nm=\&t ype $=$ Publishing $\&$ mod $=$ Publications $\% 3 \mathrm{~A} \% 3 \mathrm{AArticle} \&$ mid $=8 \mathrm{~F} 3 \mathrm{~A}$ 7027421841978F18BE895F87F791\&tier $=4 \& i d=A 2732 D 4641 \mathrm{~A}$ 14997ACD520D18F314EAA>.

25. Vacek J. Próteses plásticas com base de poliamidas: bibliografia referente aos termoplásticos produzidos pela Flexite Company. New York: Flexite Company; 1999.

26. Pronych GJ, Sutow EJ, Sykora O. Dimensional stability and dehydration of a thermoplastic polycarbonate-based and two PMMA-based denture resins. J Oral Rehabil. 2003;30(12):115761.

27. Yunus N, Rashid AA, Azmid LL, Abu-Hassan I. Some flexural properties of a nylon denture base polymer. J Oral Rehabil. 2005;32(1):65-71.
Received on: 26/4/2013

Final version resubmitted on: 13/7/2013

Approved on: 12/8/2013 